Indonesian Journal of Physics and Nuclear Applications

Volume 2, Number 2, June 2017, p. 54-64

e-ISSN 2550-0570, (c) FSM UKSW Publication

\title{
An Optimization Design of Collimator in The Thermal Column of Kartini Reactor For BNCT
}

\author{
M. Ibnu Khaldun ${ }^{a *}$, Andang Widi Harto ${ }^{a}$, Yohannes Sardjono ${ }^{b}$ \\ aDepartemen Teknik Nuklir dan Teknik Fisika FT UGM, Jl. Grafika 2 Yogyakarta \\ 55281 INDONESIA \\ ${ }^{\mathrm{b} 3}$ Centre for Accelerator Science and Technology - BATAN
}

\begin{abstract}
Studies were carried out to design a collimator which results in epithermal neutron beam for in vivo experiment of Boron Neutron Capture Therapy (BNCT) at the Kartini Research Reactor by means of Monte Carlo NParticle (MCNP) codes. Reactor within $100 \mathrm{~kW}$ of thermal power was used as the neutron source. All materials used were varied in size, according to the value of mean free path for each material. MCNP simulations indicated that by using $6 \mathrm{~cm}$ thick of Natural Nickel as collimator wall, $65 \mathrm{~cm}$ thick of Al as moderator, $3 \mathrm{~cm}$ thick of Ni-60 as filter, 6 $\mathrm{cm}$ thick of $\mathrm{Bi}$ as $\gamma$-ray shielding, $3.5 \mathrm{~cm}$ thick of $\mathrm{Li}_{2} \mathrm{CO}_{3}$-polyethilene, with $2 \mathrm{~cm}$ aperture diameter. Epithermal neutron beam with maximum flux of $6.60 \times 10^{8} \mathrm{n} \cdot \mathrm{cm}^{-2} \cdot \mathrm{s}^{-1}$ could be produced. The beam has minimum fast neutron and $\gamma$-ray components of, respectively, $1.82 \times 10^{-13} \mathrm{~Gy} \cdot \mathrm{cm}^{2} \cdot \mathrm{n}^{-1}$ and $1.70 \times 10^{-13} \mathrm{~Gy} \cdot \mathrm{cm}^{2} \cdot \mathrm{n}^{-1}$, minimum thermal neutron per epithermal neutron ratio of 0.041 , and maximum directionality of 2,12 . It did not fully pass the IAEA's criteria, since the epithermal neutron flux was below the recommended value, $1.0 \times 10^{9} \mathrm{n} . \mathrm{cm}^{-2} \cdot \mathrm{s}^{-1}$. Nonetheless, it was still usable with epithermal neutron flux exceeding $5.0 \times 10^{8} \mathrm{n} \cdot \mathrm{cm}^{-2} . \mathrm{s}^{-1}$. it is still feasible for BNCT in vivo experiment.
\end{abstract}

Keywords BNCT, Kartini reactor, Thermal Column, IAEA criteria.

\section{INTRODUCTION}

There were an estimated 14.1 million cancer cases around the world in 2012, of these. This number is expected to increase to 24 million by 2035 (Ferlay,2014). These facts lead to a consideration that eradicating the tumor cells as soon as possible is needed before it spreads to any nearby normal cells. There are several kinds of treatment to cure the disease or considerably prolong life while improving the patient's quality of life. Those treatments are, generally, sorted into 3 majors: surgery, radiotherapy, and systemic therapy. Neutron capture therapy (NCT) is a noninvasive method for the treatment of the malignant tumors like primary brain tumor and recurrent head and neck cancer. It is a selective or near to selective treatment with compare to any other methods.
In theory, boron neutron capture therapy (BNCT) selectively kills the cancerous cells and do not or little affect the normal cells. It works on the principle of the nuclear reaction, when the nonradioactive boron captures the neutron and getting unstable. In method, boron-10 (10B), which is a nonradioactive constituent of natural elemental boron, is irradiated with low-energy thermal neutrons to yield high linear energy transfer (LET) $\alpha$ particles (4He) and recoiling lithium-7 (7Li) nuclei:

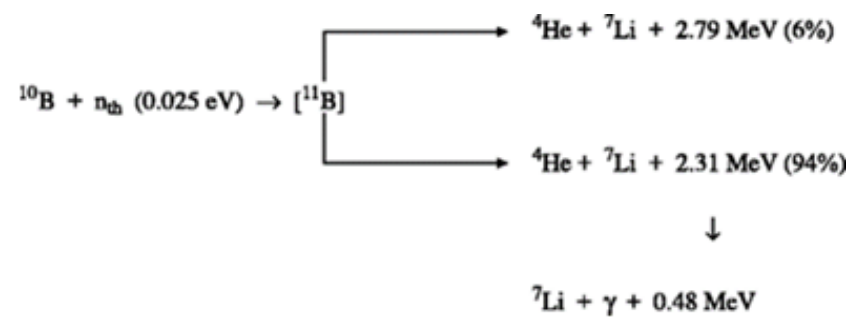

For the success of the method first of all we have to selectively deliver required dose of the 
boron to the cancerous cells and the enough thermal neutrons must be absorbed by the boron, which is present in the cancerous cells. For the selective delivery of the boron we can use the antibody based selective rug delivery system or the any other selective drug delivery system (Barth, 2012). Because the high LET particles have limited path lengths in tissue (5$9 \mu \mathrm{m})$, the destructive effects of these highenergy particles is limited to boron containing cells.

Since BNCT method requires the source of the neutrons it requires the nuclear reactor or it can be performed in the hospitals where the alternative source of neutrons is available. A beam of epithermal neutrons penetrates the brain tissue, reaching the malignancy. Once there the epithermal neutrons slow down and these low-energy neutrons combine with boron-10 (delivered beforehand to the cancer cells by drugs or antibodies) to form boron-11, releasing lethal radiation (alpha particles and lithium ions) that can kill the tumor(Teruyoshi et al,2014).

In TRIGA MARK-II type research reactor in Yogyakarta, which has also been known as Kartini Research Reactor, the facility for BNCT is going to be built for an advanced study which uses tumor injected animals as the object. The thermal column of this reactor is planned to be implanted with a device which is capable of narrowing the neutron beam, called as collimator. Due to the tendency of epithermal neutron beams usage for BNCT, the collimator must contains materials needed to produce epithermal neutron beam which fulfill some particular characteristics recommended by the International Atomic Energy Agency (IAEA). Thus, a proper collimator has to be designed.(Chiragkumar et al,2015).

\section{MATERIAL AND METHODS}

This study was a simulation-basic experiment, using MCNP5 program. As the first step, it was needed to make a model of the reactor since it would be used as the neutron source. Several parts of the reactor, whose existence were considered to affect to the reactor criticality, were modelled, such as core, the radial reflector, rotary specimen rack, and piercing beam port. Reactor core configuration was made for thermal power of $100 \mathrm{~kW}$. The thermal column was also built since it would become the point of interest; where the collimator would be built. Simulations was done to make sure that the criticality value was approximately 1 , and the thermal neutron flux in the ring B was near $(12.45+0.23) \times 1011{\mathrm{n} . \mathrm{cm}^{-2} \mathrm{~s}^{-}}^{-}$ 1 . The result should be written (recorded) for the next collimator conceptual designing process. 


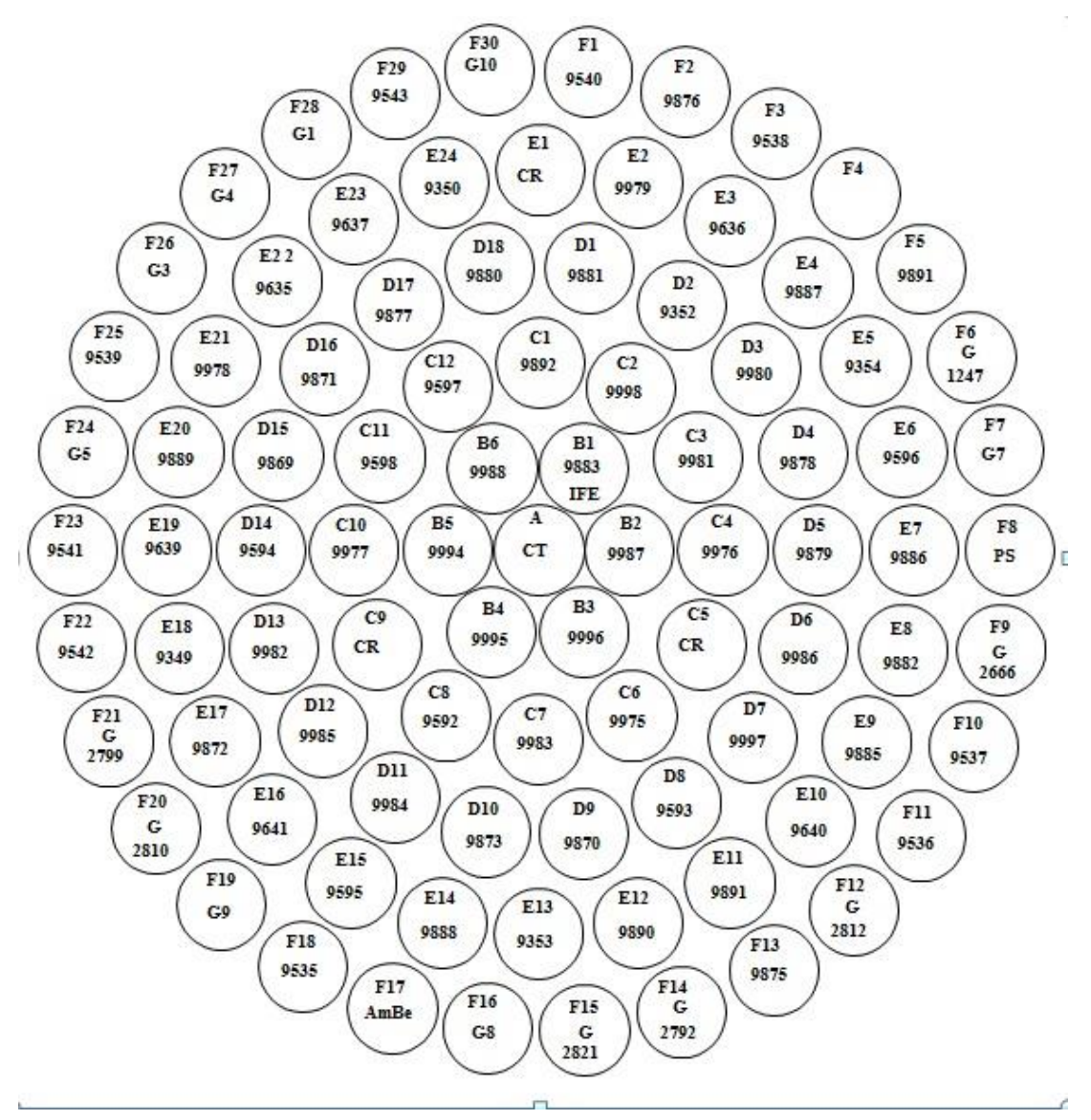

Figure.1. Core configuration of Kartini Reactor

In an MCNP input file, tallies are the information that a user wants to obtain by Monte Carlo calculation. According to the beam criteria in Table 1 , the tallies needed were those for resulting fluxes and current data. Neutron and gamma fluxes were calculated using F4 tally and corresponding dose values were determined using fluence to kerma conversion factors reported in ICRU 63. Moreover, neutron current was calculated using F1 tally. Normalization factors for each tally were calculated, used for normalizing the tallies for a reactor within $100 \mathrm{~kW}$ thermal power.

Table 1 shows the beam criteria recommended by the IAEA. The energy limits of $5 \times 10^{-7}, 10^{2}$, and $20 \mathrm{MeV}$ were used which, respectively, denoted the upper limit for thermal, epithermal, and fast neutrons energy spectrums. In this table, $\Phi_{\text {epi }}, \Phi_{\text {th }}$, and $\mathrm{J}$ are epithermal neutron flux, thermal neutron flux, and neutron current, respectively. Moreover, Df and $D \gamma$ stand for dose rates due to the fast neutrons and gamma rays.

Table 1. Beam criteria recommended by the IAEA (TECDOC-1223)

\begin{tabular}{|l|l|}
\hline Parameter & Nomenclature \\
\hline Epithermal beam intensity & $\Phi_{\text {epi }}\left(\mathrm{n} . \mathrm{cm}^{-2} \cdot \mathrm{s}^{-1}\right)$ \\
\hline $\begin{array}{l}\text { Fast neutron dose per } \\
\text { epithermal neutron }\end{array}$ & $\begin{array}{l}\dot{\mathrm{D}}_{\mathrm{f}} / \Phi_{\text {epi }} \\
\left(\mathrm{Gy} \cdot \mathrm{cm}^{2} \cdot \mathrm{n}^{-1}\right)\end{array}$ \\
\hline $\begin{array}{l}\text { Gamma dose per epithermal } \\
\text { neutron }\end{array}$ & $\begin{array}{l}\dot{\mathrm{D}}_{\gamma} / \Phi_{\mathrm{epi}} \\
\left(\mathrm{Gy} \cdot \mathrm{cm}^{2} \cdot \mathrm{n}^{-1}\right)\end{array}$ \\
\hline $\begin{array}{l}\text { Ratio between thermal flux } \\
\text { and epithermal flux }\end{array}$ & $\Phi_{\mathrm{th}} / \Phi_{\mathrm{epi}}$ \\
\hline $\begin{array}{l}\text { Ratio between neutron } \\
\text { current and neutron flux }\end{array}$ & $\mathrm{J} / \Phi_{\text {epi }}$ \\
\hline
\end{tabular}


Several experiences in designing collimator for BNCT have been conducted both based on the materials selection and the geometry optimisation. A collimator consists of 5 components: collimator wall, moderator, filter, $\gamma$-ray shielding, and aperture.

Then, the collimator designing was conducted. A rough collimator design was made by using MCNP5 codes: $100 \mathrm{~cm}$ length of collimator, $54 \mathrm{~cm}$ of outer collimator diameter. Beam delimiter used was made of ${ }^{6} \mathrm{Li}_{2} \mathrm{CO}_{3}$-polyethylene. In designing collimator, one should start with the varied size of collimator wall. Material used was Ni. The best thickness would be that the thickness which provided the highest epithermal neutron flux. Then, moderator, Al, was varied until the fast neutron component decrement no longer significant. In this point, ${ }^{60} \mathrm{Ni}$ as fast neutron absorber, which in fact also absorbed the thermal neutrons, was started to be used and varied until the fast and thermal neutron components desired reached. The next step was to employ $\mathrm{Bi}$, as $\gamma$-ray shielding into the collimator and alter its thickness until the desired $\gamma$-ray component gained. The last parameter of beam quality, the directionality, was checked right after. If the directionality was less than desired, more beam delimiter would be added. The last step conducted was varying the aperture or the beam cross section size to find out the performance of the collimator design in different aperture size.

\section{RESULT AND DISCUSSION}

The Results and Discussion should be presented with clarity and precision. The results should be written in the past tense when describing findings in the author(s)'s experiments. Previously published findings should be written in the present tense. Results should be explained, but largely without referring to the literature. Discussion, speculation and detailed interpretation of data should not be included in the results but should be put into the discussion section and also should interpret the findings in view of the results obtained in this and in past studies on this topic. State the conclusions in a few sentences at the end of the paper. The Results and Discussion sections can include subheadings, and when appropriate, both sections can be combined.

\subsection{Collimator Wall}

All materials are recommended as a collimator wall tested by simulation using MCNP. The simulation results with variations in the thickness of $3 \mathrm{~cm}$ to $10 \mathrm{~cm}$ various materials shown in Figure 1.

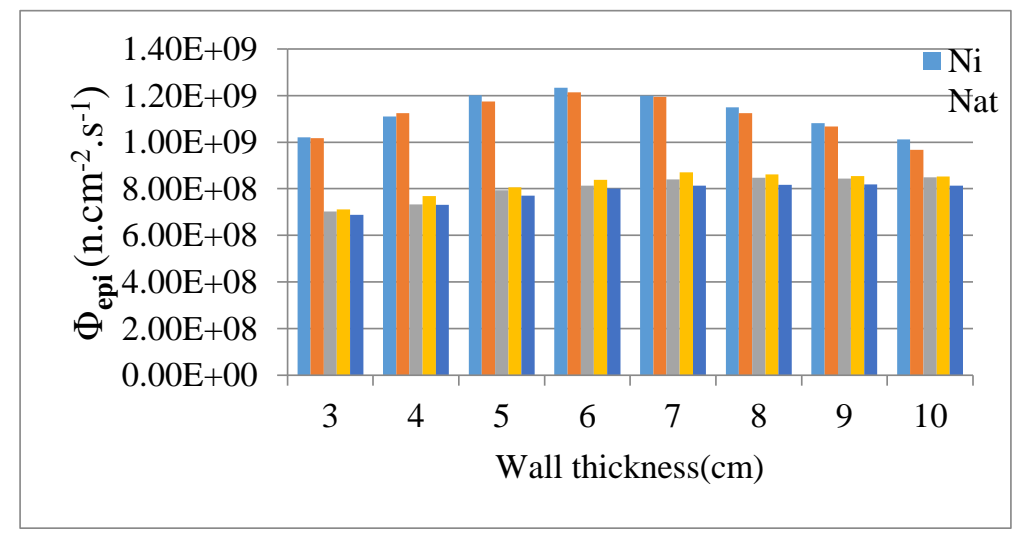

Figure.2. Epithermal flux comparison for various materials of collimator wall 


\subsection{Moderator}

As shown as Figure.1 the best material to maintain the neutron is Nickel natural. Epithermal neutron flux which are reflected by the collimator wall material increased until an optimal thickness of $6 \mathrm{~cm}$. This means that the thicker wall mounted collimator which means there will be more number of neutrons which are reflected. This increase is due to a shift in the neutron energy of fast neutrons into epithermal neutron. In the next thickness, epithermal neutron flux even more down. This is due to the thickness of the wall of a larger collimator makes the inside diameter of the smaller collimator causing more collisions between neutron collimator wall and causing a shift in the neutron energy growing up to run through the area of epithermal towards thermal area. Natural nickel is a very good material to be employed as a neutron collimator wall. Its atomic mass which is not too small, that would make too much energy decrement of neutrons, and yet not too high, that only would slightly shift.

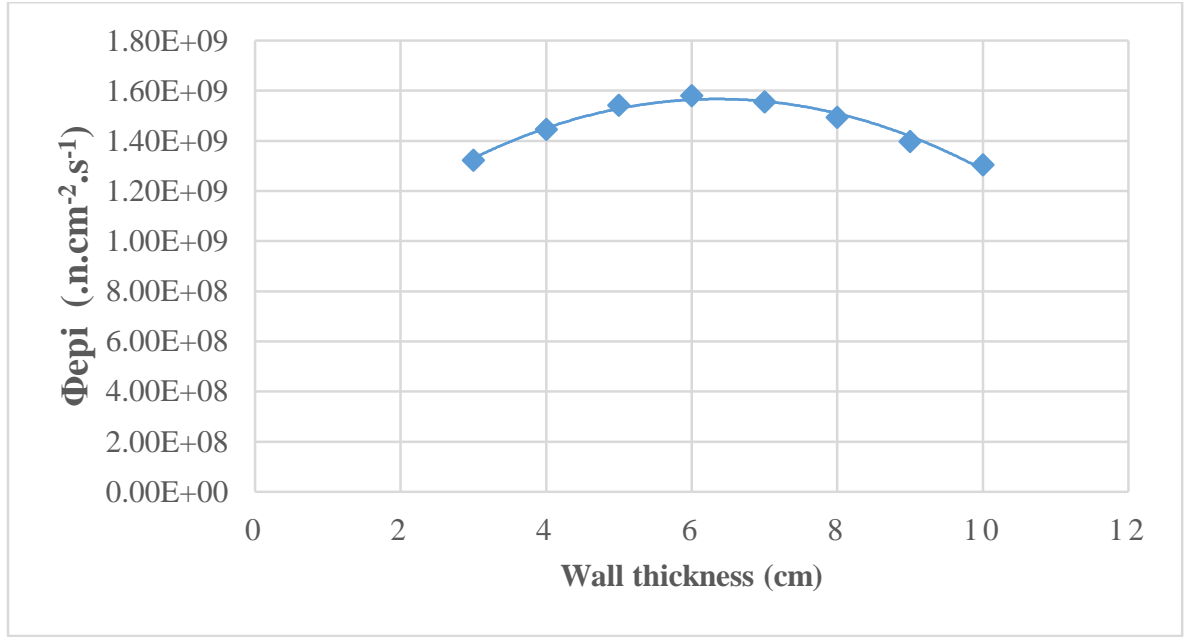

Figure.3. Epithermal neutron flux for various thickness of wall (Ni)

As shown in Figure 2, the flux increases when 3 to $10 \mathrm{~cm}$ of wall thickness is used.

The thicker the collimator wall, the more neutrons would be reflected. The flux reaches its highest value $\left(1.58 \times 10^{9} \mathrm{n} . \mathrm{cm}^{-2} . \mathrm{s}^{-1}\right)$ in thickness of $6 \mathrm{~cm}$.

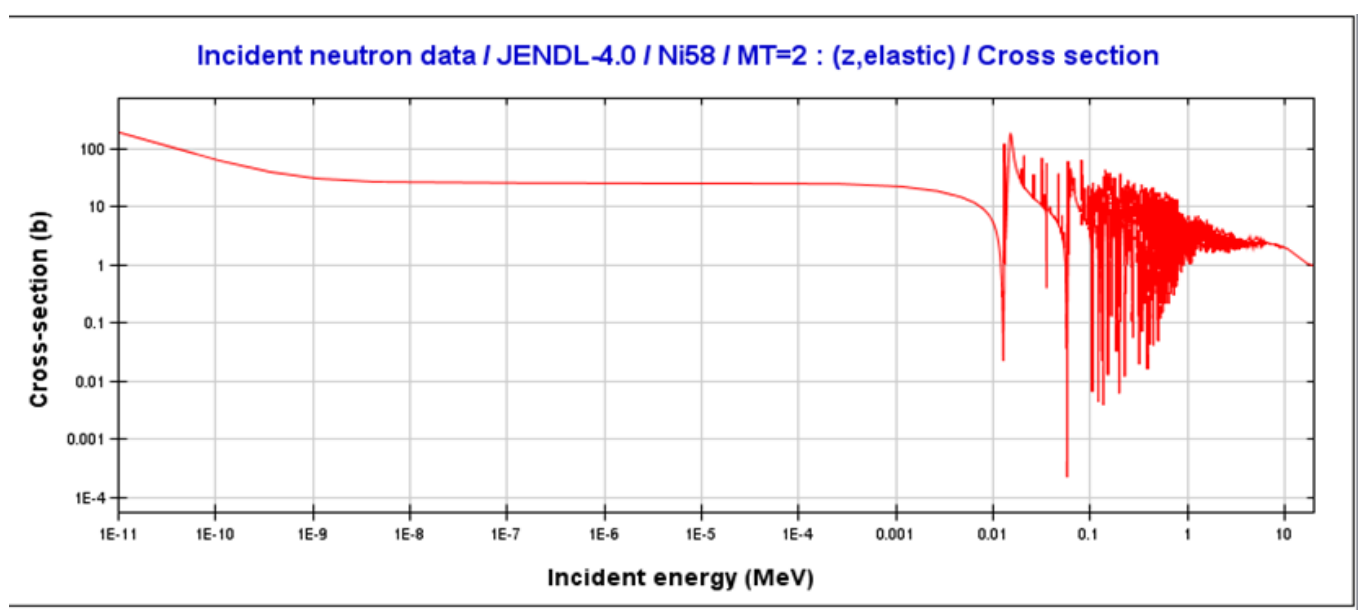

Figure.4. ${ }^{58} \mathrm{Ni}$ Scattering cross section (JANIS,2012) 


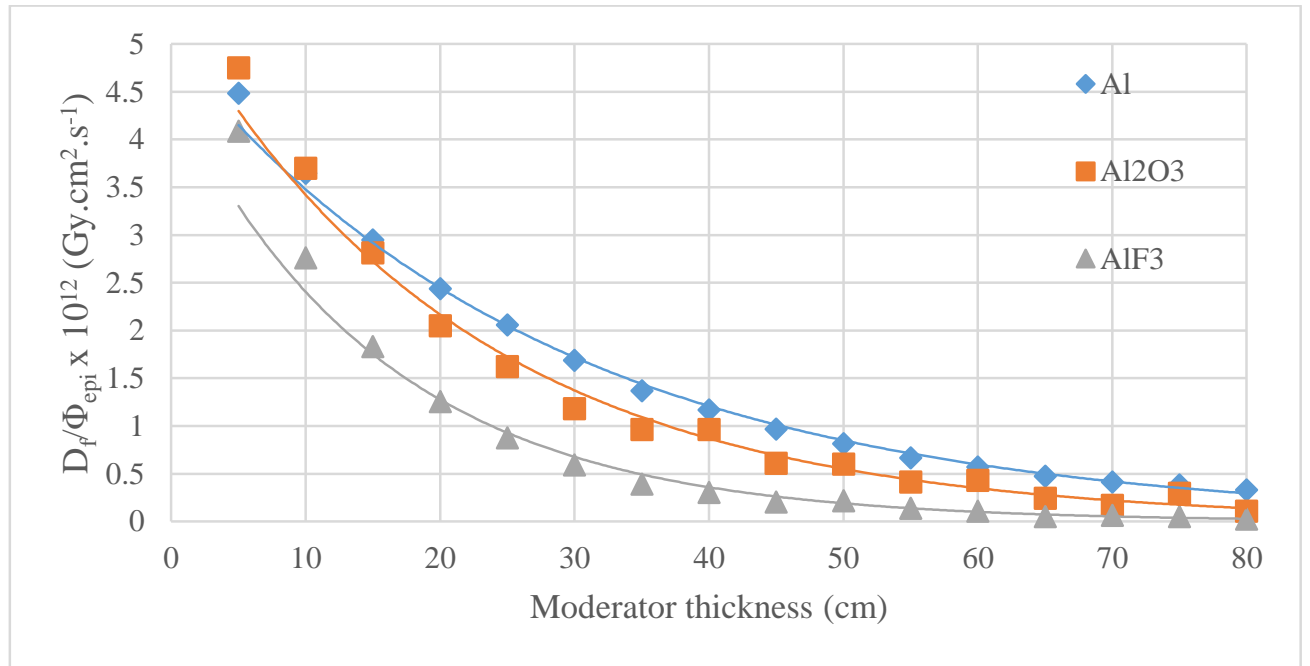

Figure.5. Fast neutron component for various material of moderator

From the graph we can see that the thicker the wall thickness will reduce the value of fast neutron component (D́f/Фepi). And we'll get that material AlF3 has the potential to moderate the fast neutrons is better than the material of $\mathrm{Al}$ and $\mathrm{Al}_{2} \mathrm{O}_{3}$. However, if we compare the number of epithermal neutron flux needed BNCT, look at the chart shows that the Al material better in epithermal neutron forward than the other two materials.

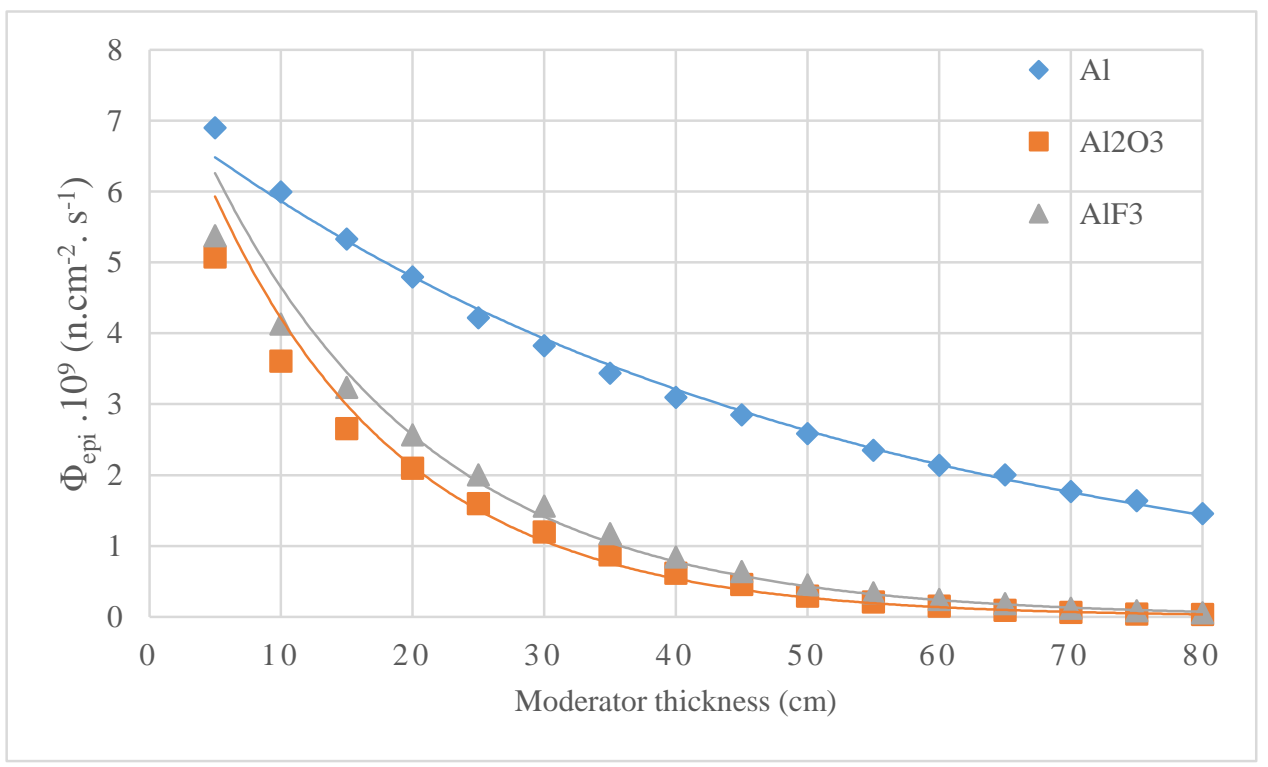

Figure.6. Epithermal flux for various material of moderator

Because of the IAEA requires epithermal flux minimum amount allowed is $10^{9} \mathrm{n} . \mathrm{cm}^{2} . \mathrm{s}^{-}$ ${ }^{1}$, the material $\mathrm{Al}_{2} \mathrm{O}_{3}$ and $\mathrm{AlF}_{3}$ is not selected, resulting in the value of the thickness of the moderator is made of $35 \mathrm{~cm}$, Фepi its value is below the minimum limit. 


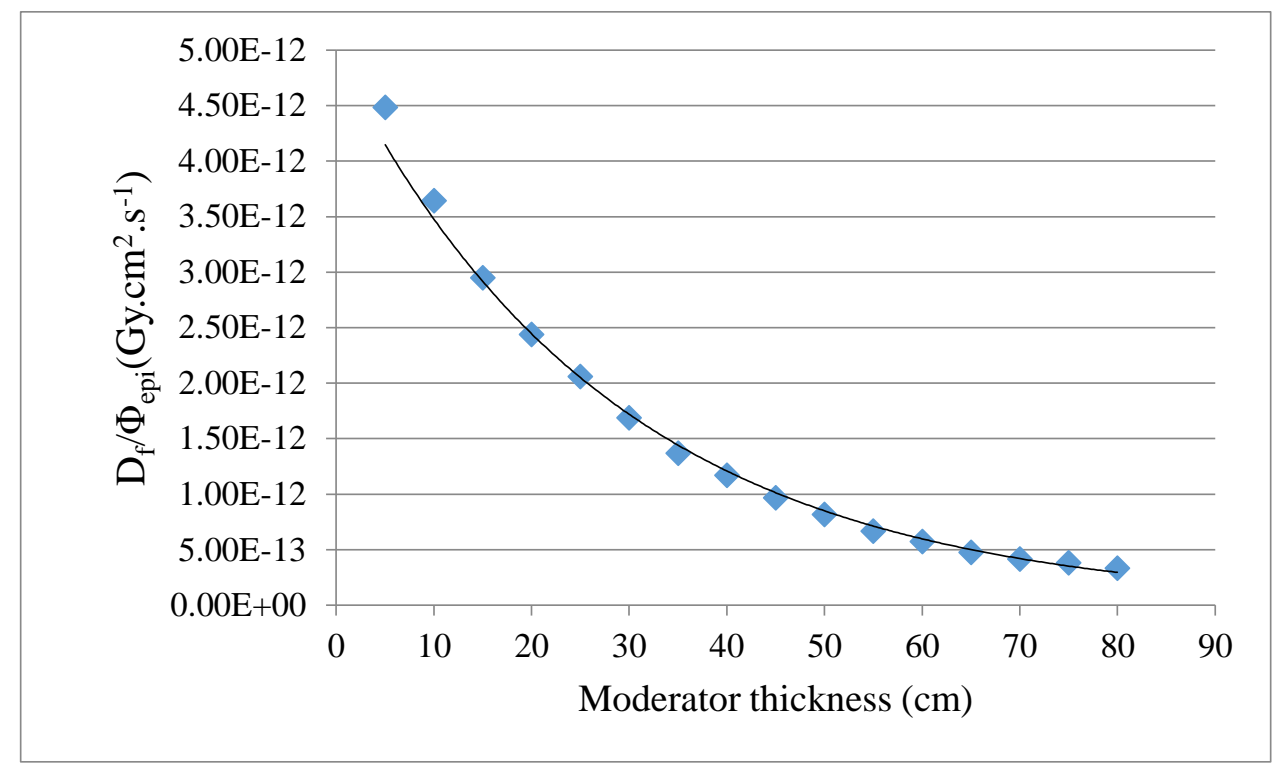

Figure.7. Fast neutron component for various thickness of moderator (Al)

From the above chart it is known that a decrease in fast neutron component decreased exponentially with the addition of material Al. For that we chose the moderator made of aluminum with a thickness of $65 \mathrm{~cm}$ for collimator which we design, because at this thickness and subsequent relatively stable.

\subsection{Filter}

By using Ni-60 material as a filter, obtained graph:

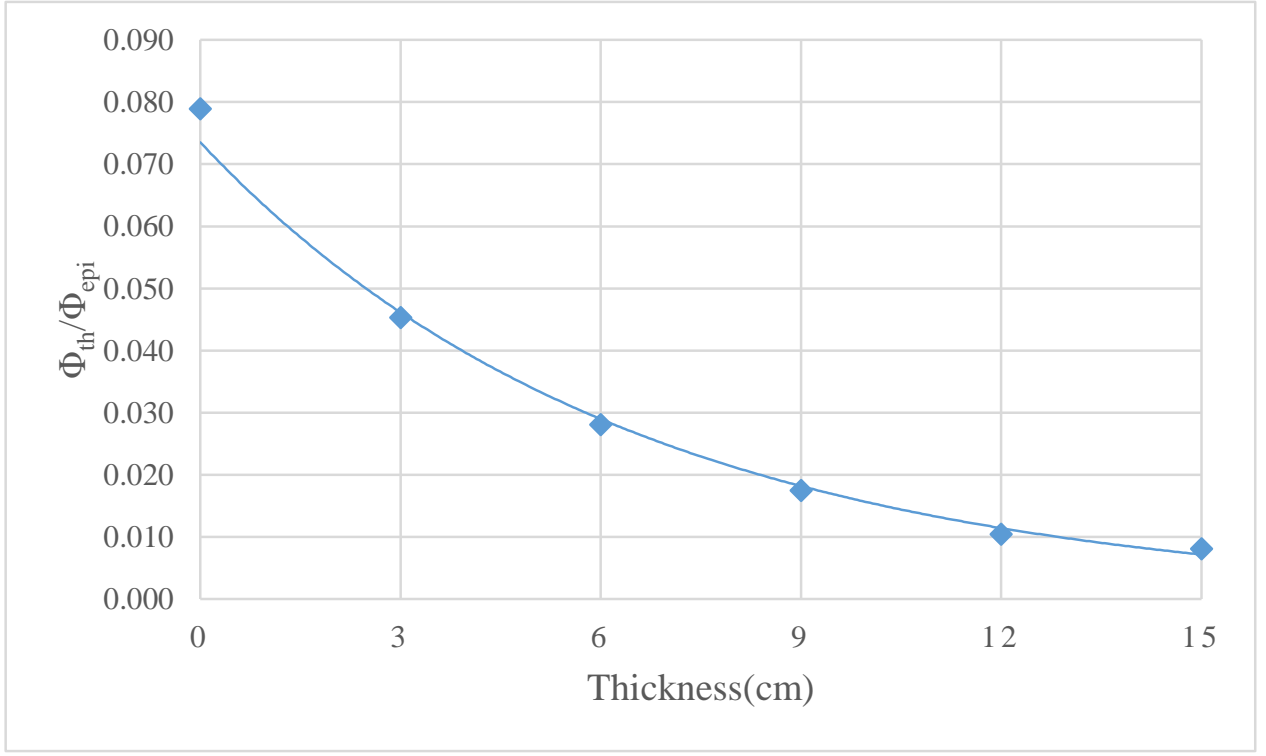

Figure.8. Fast neutron component for various thickness of filter $\left({ }^{60} \mathrm{Ni}\right)$ In Figure.6 shows that the Ni-60 Filter thickness of $3 \mathrm{~cm}$ was able to meet the requirements of the IAEA that the value $\Phi$ th/Фepi already less than 0.05 . The simulation results show that the value $\Phi$ th/ $/$ epi Ni-60 at a thickness of $3 \mathrm{~cm}$ which is equal to 0.0453 . 


\subsection{Filter}

Table.2. Results of $\gamma$-ray shielding (Bi) thickness variations.

\begin{tabular}{|c|c|c|c|c|c|}
\hline Thickness & $\Phi_{\text {epi }}$ & $\dot{D}_{\mathrm{f}}$ & $\dot{D}_{\gamma}$ & $\dot{D}_{\mathrm{f}} / \Phi_{\text {epi }}$ & $\dot{D}_{\gamma} / \Phi_{\text {epi }}$ \\
\hline 1 & $1.02 \mathrm{E}+09$ & $4.27 \mathrm{E}-04$ & $5.45 \mathrm{E}-04$ & $4.18 \mathrm{E}-13$ & $5.33 \mathrm{E}-13$ \\
\hline 2 & $9.60 \mathrm{E}+08$ & $3.79 \mathrm{E}-04$ & $4.37 \mathrm{E}-04$ & $3.94 \mathrm{E}-13$ & $4.55 \mathrm{E}-13$ \\
\hline 3 & $9.36 \mathrm{E}+08$ & $3.90 \mathrm{E}-04$ & $3.47 \mathrm{E}-04$ & $4.16 \mathrm{E}-13$ & $3.71 \mathrm{E}-13$ \\
\hline 4 & $9.19 \mathrm{E}+08$ & $3.81 \mathrm{E}-04$ & $3.23 \mathrm{E}-04$ & $4.15 \mathrm{E}-13$ & $3.52 \mathrm{E}-13$ \\
\hline 5 & $8.95 \mathrm{E}+08$ & $3.64 \mathrm{E}-04$ & $2.89 \mathrm{E}-04$ & $4.06 \mathrm{E}-13$ & $3.23 \mathrm{E}-13$ \\
\hline 6 & $8.69 \mathrm{E}+08$ & $3.42 \mathrm{E}-04$ & $2.30 \mathrm{E}-04$ & $3.94 \mathrm{E}-13$ & $2.64 \mathrm{E}-13$ \\
\hline
\end{tabular}

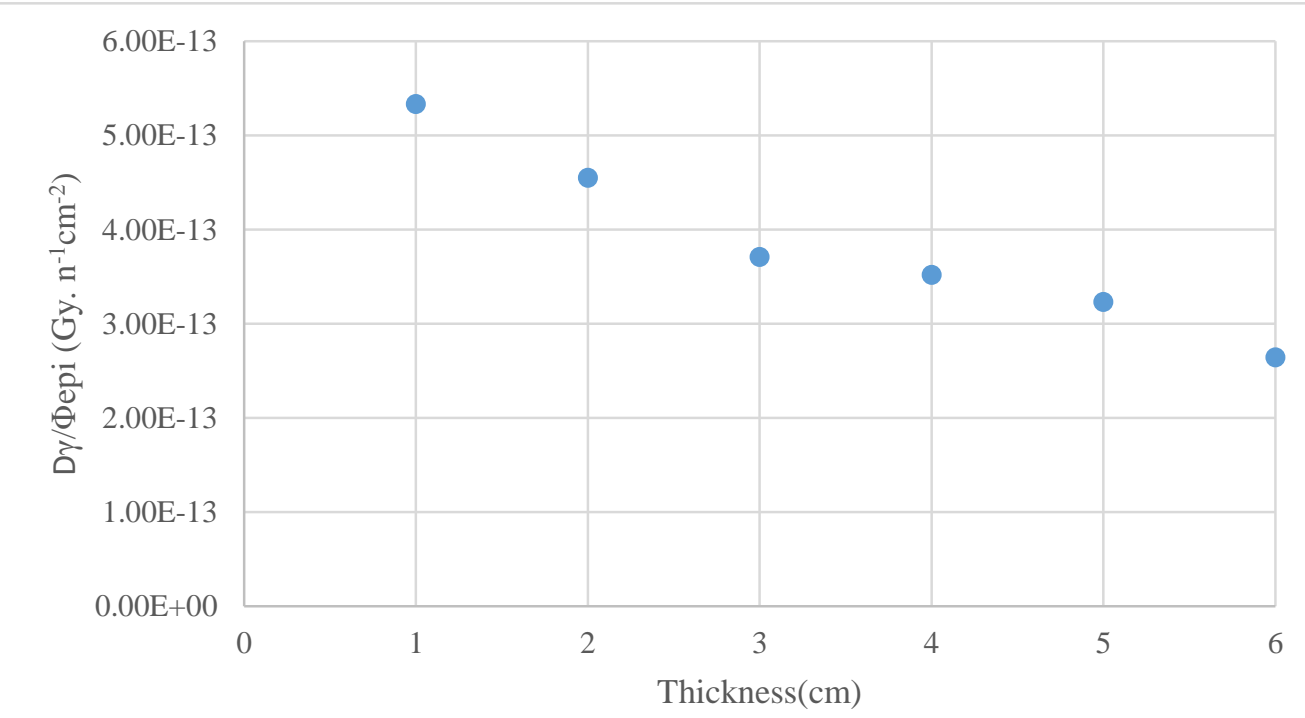

Figure.9. Gamma dose ratio per epithermal flux for various thickness of Bi Of all the gamma shield thickness variations, none of which meet the requirements of the IAEA (less than $2 \times 10^{-13} \mathrm{~Gy} \cdot \mathrm{n}^{-1} \mathrm{~cm}^{-2}$ ), therefore we chose $6 \mathrm{~cm}$ thick Bi material which has a value $\dot{\mathrm{D}} \gamma / \Phi$ epi amounted to $2.64 \times 10^{-13} \mathrm{~Gy} \cdot \mathrm{n}^{-1} \mathrm{~cm}^{-2}$, the value of which is slightly greater than the maximum limit $\mathrm{D} \gamma /$ Фepi required by the IAEA that is $2.0 \times 10^{-13} \mathrm{~Gy} \cdot \mathrm{n}^{-1} \mathrm{~cm}^{-2}$.

Table 5.2. Results of beam characteristics for various aperture diameter.

\begin{tabular}{|l|l|l|l|}
\hline$\phi 61$ perture $(\mathrm{cm})$ & 3 & 4 & 5 \\
\hline$\Phi_{\text {epi }}\left(\mathrm{n} \mathrm{cm}^{-2} \mathrm{~s}^{-1}\right)$ & $6.86 \mathrm{E}+08$ & $5.48 \mathrm{E}+08$ & $6.97 \mathrm{E}+08$ \\
\hline$\dot{D}_{f} / \Phi_{\text {epi }}\left(\mathrm{Gy}^{-1} \mathrm{n}^{-1} \mathrm{~cm}^{2}\right)$ & $1.55 \mathrm{E}-13$ & $2.86 \mathrm{E}-13$ & $3.02 \mathrm{E}-13$ \\
\hline$\dot{D} \gamma / \Phi_{\text {epi }}\left(\mathrm{Gy} \cdot \mathrm{n}^{-1} \mathrm{~cm}^{2}\right)$ & $3.89 \mathrm{E}-13$ & $3.21 \mathrm{E}-13$ & $1.65 \mathrm{E}-13$ \\
\hline$\Phi_{\text {th }} / \Phi_{\text {epi }}$ & 0.0276 & 0.0758 & 0.0385 \\
\hline $\mathrm{J} / \Phi_{\text {epi }}$ & 0.736 & 1.5 & 2.1 \\
\hline
\end{tabular}


This collimator design does not fully pass the IAEA's criteria, since the epithermal neutron flux is always below the recommended value of $1.0 \times 10^{9} \mathrm{n} \cdot \mathrm{cm}^{-2} . \mathrm{s}^{-1}$.
And the fast neutron component is above $2.0 \times 10^{-}$ ${ }^{13} \mathrm{~Gy} \cdot \mathrm{n}^{-1} \cdot \mathrm{cm}^{-2}$. Furthermore, the optimization of the thickness of Li2CO3-polyethylene as follows:

\begin{tabular}{|c|c|c|c|c|c|}
\hline $\begin{array}{c}\text { Thick. } \\
(\mathrm{cm})\end{array}$ & $\begin{array}{c}\Phi_{\text {epi }} \\
\left(\mathrm{n} \mathrm{cm}^{-2} \mathrm{~s}^{-1}\right)\end{array}$ & $\begin{array}{c}\dot{D}_{f} / \Phi_{\text {epi }} \\
\left(\mathrm{Gy} . \mathrm{n}^{-1} \mathrm{~cm}^{2}\right)\end{array}$ & $\begin{array}{c}\dot{D} \gamma / \Phi_{\text {epi }} \\
\left(\mathrm{Gy} \cdot \mathrm{n}^{-1} \mathrm{~cm}^{2}\right)\end{array}$ & $\Phi_{\text {th }} / \Phi_{\text {epi }}$ & $\mathrm{J} / \Phi_{\text {epi }}$ \\
\hline 0.5 & $6.78 \mathrm{E}+08$ & $2.95 \mathrm{E}-13$ & $1.88 \mathrm{E}-13$ & 0.077 & 2.12 \\
\hline 1 & $6.66 \mathrm{E}+08$ & $3.35 \mathrm{E}-13$ & $1.70 \mathrm{E}-13$ & 0.056 & 2.15 \\
\hline 1.5 & $6.99 \mathrm{E}+08$ & $2.86 \mathrm{E}-13$ & $2.18 \mathrm{E}-13$ & 0.041 & 2.01 \\
\hline 2 & $6.93 \mathrm{E}+08$ & $3.12 \mathrm{E}-13$ & $2.51 \mathrm{E}-13$ & 0.045 & 2.10 \\
\hline $\mathbf{2 . 5}$ & $\mathbf{6 . 9 7 E + 0 8}$ & $\mathbf{3 . 0 2 E}-13$ & $\mathbf{1 . 6 5 E}-13$ & $\mathbf{0 . 0 3 8}$ & $\mathbf{2 . 1 0}$ \\
\hline 3 & $7.17 \mathrm{E}+08$ & $2.34 \mathrm{E}-13$ & $1.66 \mathrm{E}-13$ & 0.052 & 2.08 \\
\hline $\mathbf{3 . 5}$ & $\mathbf{6 . 6 0 E}+\mathbf{0 8}$ & $\mathbf{1 . 8 2 E}-13$ & $\mathbf{1 . 7 0 E}-13$ & $\mathbf{0 . 0 4 1}$ & $\mathbf{2 . 1 2}$ \\
\hline 4 & $5.94 \mathrm{E}+08$ & $4.59 \mathrm{E}-13$ & $1.89 \mathrm{E}-13$ & 0.047 & 2.24 \\
\hline 4.5 & $5.77 \mathrm{E}+08$ & $5.63 \mathrm{E}-13$ & $1.85 \mathrm{E}-13$ & 0.059 & 2.25 \\
\hline
\end{tabular}

From the start delimiters thickness of 2.5 $\mathrm{cm}$, the flux output parameter in the fast neutron component has improved such that can satisfy the IAEA recommendations at a maximum of $2 \times 10-13 \mathrm{~Gy} \cdot \mathrm{n}^{-1} \mathrm{~cm}^{-2}$ at a thickness of $3.5 \mathrm{~cm}$ delimiter. Thus, the end result of the optimization is carried out as follows:

\begin{tabular}{|c|c|c|}
\hline Parameter & Value & IAEA recomendation \\
\hline$\Phi_{\text {epi }}\left(\mathrm{n} \mathrm{cm}^{-2} \mathrm{~s}^{-1}\right)$ & $6.60 \times 10^{8}$ & $>10^{9}$ \\
\hline$\dot{D}_{f} / \Phi_{\text {epi }}\left(\mathrm{Gy} \cdot \mathrm{n}^{-1} \mathrm{~cm}^{2}\right)$ & $1.82 \times 10^{-13}$ & $<2 \times 10^{-13}$ \\
\hline$\dot{D} \gamma / \Phi_{\text {epi }}\left(\mathrm{Gy} \cdot \mathrm{n}^{-1} \mathrm{~cm}^{2}\right)$ & $1.70 \times 10^{-13}$ & $<2 \times 10^{-13}$ \\
\hline$\Phi_{\text {th }} / \Phi_{\text {epi }}$ & 0.041 & $<0.05$ \\
\hline $\mathrm{J} / \Phi_{\text {epi }}$ & 2.12 & $>0.7$ \\
\hline
\end{tabular}

The final results of optimization that has been done shows there is one parameter that has not been achieved according to the IAEA recommendations epithermal flux value of $6.60 \mathrm{x}$ $10^{8} \mathrm{n} \mathrm{cm}^{-2} \mathrm{~s}-1$ This value is below the recommended standard IAEA flux of more than 1 
x $10^{9} \mathrm{n} \mathrm{cm}^{-2} \mathrm{~s}^{-1}$. Although it has not reached used for more than $5 \times 10^{8} \mathrm{n} \cdot \mathrm{cm}^{2} \cdot \mathrm{s}^{-1}$. the criteria, the results are still eligible to be

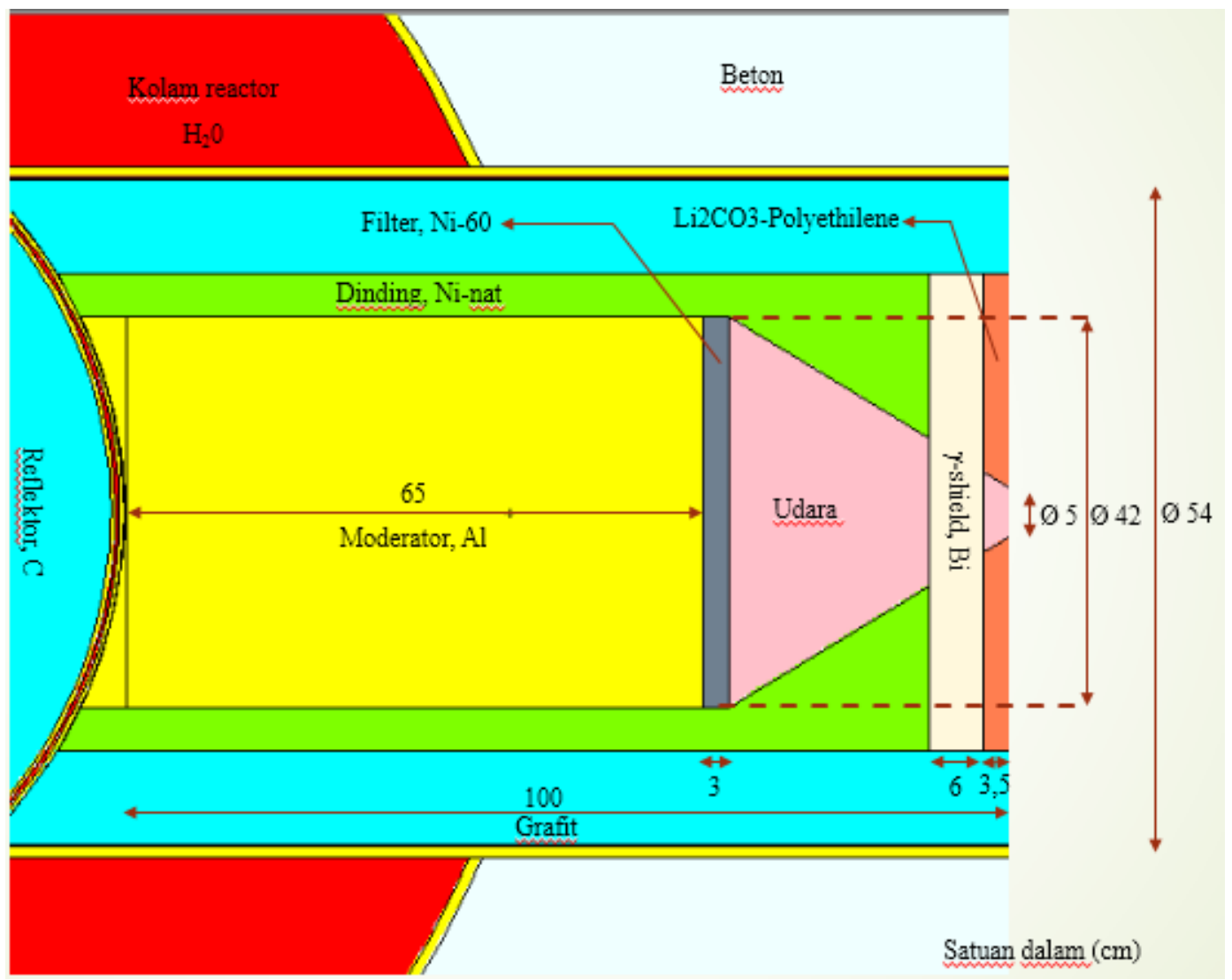

Figure.8. Collimator configuration

\section{CONCLUSION AND REMARKS}

The optimization is performed to produce:

1) Wall Collimator: Ni purity of $95 \%$ with a $6 \mathrm{~cm}$ thick

2) Moderator: Aluminium with a length of $65 \mathrm{~cm}$

3) Filter: $60 \mathrm{Ni}$ with a thickness of $3 \mathrm{~cm}$

4) Shield $\gamma$ : Bi with optimum thickness of $6 \mathrm{~cm}$.

5) Beam delimiters: $\mathrm{Li} 2 \mathrm{CO} 3$ with a diameter of $5 \mathrm{~cm}$ and a diameter of 3.5

Output beam from the design shown in the following five parameters:

$$
\begin{array}{ll}
\text { Фepi } & : 6.60 \times 10^{8} \mathrm{n} \cdot \mathrm{cm}^{-2} \mathrm{~s}^{-1} \\
\text { Ḋf/Фepi } & : 1.82 \times 10^{-13} \mathrm{~Gy} \cdot \mathrm{n}^{-1} \mathrm{~cm}^{2} \\
\text { Ḋ } / \text { Фepi } & : 1.70 \times 10^{-13} \mathrm{~Gy} \cdot \mathrm{n}^{-1} \mathrm{~cm}^{2} \\
\text { Фth/Фepi } & : 0.041 \\
\text { J/Фepi } & : 2.12
\end{array}
$$

\section{REFERENCES}

Barth, Rolf F. et al. (2012) "Current Status of Boron Neutron Capture Therapy of HighGrade Gliomas and Recurrent Head and Neck Cancer" Radiation Oncology, 7, 1-21. http://www.rojournal.com/content/7/1/146

Chamber, Herman \& Johnson, Thomas E.(2009) Introduction to Health Physics, 4th Edition. New York: McGraw-Hill. 
Chiragkumar J. Gohil, Malleshappa N. Noolvi., (2015)“'Selective Cancer Treatment by Boron Neutron Capture Therapy (BNCT)". International Journal Pharmaceutical Chemistry and Analysis. 7, 136-138.

D. Rorer, A. Wambersie, G. Whitmore, R. Zamenhof, V. Levin, P. Andreo, and B. Dodd.(2001).Current Status of Neutron Capture Therapy. A technical document, IAEA-TECDOC-1223, International Atomic Energy Agency, Vienna.

Fauziah, Nina et al. (2013)“A Conceptual Design Of Neutron Collimator In The ThermalColumn Of Kartini Research Reactor For In Vitro And In Vivo Test Of Boron Neutron Capture Therapy". Jurnal Teknologi Reaktor Nuklir.

Ferlay J, et al.. GLOBOCAN 2012 v1.1, (2014) Cancer Incidence and Mortality Worldwide: IARC CancerBase No. 11 [Internet]. Lyon, France: International Agency for Research on Cancer; Available from: http://globocan.iarc.fr, accessed on 19/07/2016.

Ilma, M. (2013). Perancangan Kolimator di Beam Port Tembus Reaktor Kartini untuk Boron Neutron Capture Therapy.(Unpublished undergraduate's thesis) Yogyakarta: Universitas Gadjah Mada.

Kageji, Teruyoshi et al.(2014). "Boron Neutron Capture Therapy (BNCT) for Newly-Diagnosed Glioblastoma: Comparison of Clinical Results obtained with BNCT and Conventional Treatment" The Journal of Medical Investigation, 61, 254-263

Koivunoro, H. (2012). Dosimetry and dose planning in boron neutroncapture therapy, Monte Carlo studies. Helsinki: Department of Physics Faculty of Science University of Helsinki .

Laporan Analisis Keselamatan Reaktor Kartini. A technical document, C7/05/B2/LAK/2005, Pusat Teknologi Akselerator dan Proses Bahan Badan
Tenaga Nuklir Nasional, Yogyakarta,2005. Maucec., Marko.(1998) Conceptual Design of Epithermal Neutron Beam for BNCT in Thermal Column of TRIGA Reactor. Nuclear Energy in Central Europe, Ljubljana.

Mukawa, T., Matsumoto, T., \& Niita, K. (2011). Progress in Nuclear Science and Technology. Study on Microdosimetry for Boron Neutron Capture Therapy, 2:242.

N. Soppera, E. Dupont, and M. Bossant. (2012) Java-based Nuclear Information

Software (JANIS): Book of Neutron-induced Cross-sections. A technical document, Nuclear Energy Agency, Issy-lesMoulineaux.

Thomas E. Booth, et.al. (2003).MCNP - A General Monte Carlo NParticle Transport Code, Version 5, Volume II: Overview and Theory. A technical document, LA-CP-030245, Los Alamos National Laboratory, New Mexico

Treatment of Cancer. World Health Organization, 2013. Accessed on http://www.who.int/cancer/treatment/en/, accessed on 18/07/2016. 